\title{
Effect of agricultural programmes on the livelihood of the vulnerable group: a case study of the Fadama III programme in Kwara State, Nigeria
}

\author{
Gbolagade Benjamin ADESIJI, ${ }^{1}$ Abraham FALOLA, ${ }^{2 *}$ \\ Oladipo Gboyega ABIKOYE ${ }^{1}$ \\ ${ }^{1}$ Department of Agricultural Extension and Rural Development, \\ University of Ilorin, P. M. B. 1515, Ilorin, Kwara State, Nigeria \\ ${ }^{2}$ Department of Agricultural Economics and Farm Management, \\ University of Ilorin, P. M. B. 1515, Ilorin, Kwara State, Nigeria \\ *Corresponding author's e-mail: falolaabraham@yahoo.com; falola.a@unilorin.edu.ng
}

Manuscript received March 20, 2015; revised April 25, 2015; accepted May 29, 2015

\begin{abstract}
This study examines the contribution of the Fadama III programme to the livelihood of the vulnerable group in Kwara State, Nigeria. Results revealed that the group was made up of mainly old, less-educated, small-scale farmers, with many years of farming experience. Benefits derived from the programme by the group include input support, asset acquisition, rural infrastructure, advisory services, capacity building, increased output, and income. The major constraints faced by the group were illiteracy, pests and diseases, inadequate inputs, and untimely funding. This study suggests policy measures on how to better the livelihood of the vulnerable group of farmers.
\end{abstract}

Keywords: contribution, benefits, constraints, measures

\section{Introduction}

With 173.6 million inhabitants, Nigeria is the most populous country in West Africa and constitutes $52.4 \%$ of West Africa's population [1]. Agriculture is the mainstay of the country's economy, accounting for about $40 \%$ of the gross domestic product (GDP) and providing employment to over $60 \%$ of the labour force and $90 \%$ in rural areas $[2,3]$. Nigeria is blessed with good arable land, a friendly agricultural climate, a large consumer market - as indicated by the huge population -, as well as the ever-increasing world market for reaping the potentials 
that agriculture can offer any economy [4]. Despite these plentiful agricultural potentials, Nigeria continues to experience widespread food insecurity and poverty, with $68 \%$ of the population living on less than $\$ 1.25$ a day [5]. The vulnerable group is the worst hit in this regard [6].

One viable way of helping the vulnerable group is through interventions such as creating jobs or means of improving their livelihood [7]. Thus, in an attempt to improve the condition of the vulnerable group of its population, the Nigerian government most often includes this group of people in its agricultural intervention programmes. This group of individuals includes among others the disabled, the low-income group, the aged, unskilled population, isolated elderly people, widows, and orphans [3].

One of such agricultural-based intervention programmes is Fadama III. The programme is a tripartite intervention funded by the World Bank, the Federal Government of Nigeria, and participating States with objectives aimed at improving the livelihood of the beneficiaries (also known as Fadama User Groups - FUGs) in a sustainable manner. Though the primary focus of the project is targeted at involvement in food production, there is a tangential part involving social and economic support to vulnerable groups, such as widows, physically handicapped, the aged, and orphans, based on their identified needs.

Though many studies have focused on a generalized assessment of intervention programmes in Nigeria [8, 9, 10, 11, 12], none of them has paid specific attention to the vulnerable group as an important component of such programmes. This was the research gap which the study intended to fill. Knowledge about the clear picture of the assessment of the programme on vulnerable groups is desirable to provide agricultural policy makers an insight into the areas where the vulnerable groups require better assistance in order to improve their livelihood. In the light of this, the general objective of this study was to assess the influence of the Fadama III Development Programme on the livelihood of vulnerable crop farmers in Kwara State, Nigeria. The specific objectives were to:

1. examine the socio-economic characteristics of the vulnerable groups in the programme;

2. identify activities/services rendered by the programme to the vulnerable users;

3. determine the influence of the programme on the livelihood of vulnerable users;

4. identify the constraints confronting the group vis-à-vis their participation in the Fadama III programme. 


\section{Material and methods}

\section{Study area}

The study was carried out in Kwara State, North Central Nigeria. The state is referred to as the "State of Harmony" and is one of the 36 states that make up the Federal Republic of Nigeria. It is located between latitude $8^{0} 5^{1}-10^{0} 4^{1} \mathrm{~N}$ and longitude $4^{0} 55^{1}-6^{0} 5^{1} \mathrm{E}$, covering an estimated land area of 36,825 square $\mathrm{km}$ with a population of about 2.37 million (NPC, 2006). The state was created in 1967 and is made up of 16 Local Government Areas (LGAs). It shares national boundaries with Niger, Oyo, Kogi, and Osun states and international boundaries with the Republic of Benin.

Kwara State is within the rain forest and the woody savannah areas. The state enjoys a tropical climate with an average rainfall ranging between $1,000 \mathrm{~mm}$ and $1,500 \mathrm{~mm}$, lasting from eight to nine months of the year and a maximum temperature range of $30^{\circ} \mathrm{C}-35^{\circ} \mathrm{C}$. It experiences two climatic seasons: dry and wet seasons. Agriculture is the main source of the state's economy.

The 16 LGAs in the state are grouped by the state's Agricultural Development Project (ADP) into four zones - A, B, C, and D - with their headquarters at Kaima, Patigi, Malete, and Igbaja respectively. The grouping was done in consonance with the ecological characteristics of the various parts of the state and for the effective administration of agricultural intervention programmes. The Fadama III programme covers all the four zones in the state. The beneficiaries of the programme were classified into groups otherwise called Fadama User Groups (FUGs) based on their enterprises.

\section{Sampling procedure and sample size}

The population for the study comprised vulnerable FUG crop farmers in Kwara State, Nigeria. Four-stage sampling technique was employed in the selection of respondents for this study. The first stage was a random selection of two (2) ADP zones from the four (4) ADP strata in the state. These were Zones C and $\mathrm{D}$. The second stage involved a random selection of four (4) LGAs, two (2) from each selected ADP zone. These were Asa and Ilorin East LGAs in Zone C and Ifelodun and Irepodun LGAs in Zone D. Thirdly, with the assistance of the Fadama Community Facilitators, a list of vulnerable FUGs was compiled in each of the four LGAs, from which eight (8) vulnerable crop farmer FUG groups were randomly selected. Lastly, 185 vulnerable crop farmers were randomly selected from the eight FUGs based on the proportion of the vulnerable crop farmers in each group (Table 1). 
Table 1. Sample design outlay for the study

\begin{tabular}{cclc}
\hline $\begin{array}{c}\text { Selected } \\
\text { ADP Zone }\end{array}$ & LGAs & \multicolumn{1}{c}{$\begin{array}{c}\text { FUGs by } \\
\text { communities }\end{array}$} & $\begin{array}{c}\text { No of } \\
\text { respondents }\end{array}$ \\
\hline \multirow{3}{*}{$\mathrm{C}$} & \multirow{2}{*}{ Asa } & Alapa/Bakasse & 21 \\
& \multirow{2}{*}{ Lasoju } & 20 \\
\cline { 2 - 4 } & \multirow{2}{*}{ Ilorin East } & Agbayangi & 21 \\
& \multirow{2}{*}{ Ifelodun } & Iponrin & 22 \\
\hline \multirow{2}{*}{ D } & \multirow{2}{*}{ Orepodun } & Idera & 24 \\
& \multirow{2}{*}{ Ireponire } & 27 \\
\cline { 3 - 4 } & Ojase & 24 \\
\hline
\end{tabular}

Source: Authors' design

\section{Sources of data and instrument for data collection}

Data for the study were obtained from both primary and secondary sources. The primary data were collected with the use of interview schedule. Also, Focus Group Discussions (FGD) were conducted to make the study more interactive and participatory to determine the opinion of the groups about the context of the survey. Secondary data were also sourced from published and grey literature.

The instrument for data collection was structured questionnaire, the content of which was properly validated to ensure that the questions were relevant and without bias. The pre-testing of the instrument was carried out on 20 vulnerable FUG members in Bakasse (one of the FUG communities in Asa LGA of the state). The data collected include socio-economic characteristics of the respondents, services rendered by FADAMA III, benefits accrued from participating in the programmes, and constraints faced by the respondents vis-à-vis their participation in the programme.

\section{Data analysis}

Both descriptive statistics and Likert-type scale were used for this study. Descriptive statistics involving the use of frequencies, percentages were employed to analyse the socio-economic characteristics of the farmers and present the results of the findings. Likert-type scale was also used to assess the opinion of the farmers on how well the programme had improved their livelihood and the factors militating their ability to access the benefits of the programme. As regards the effects of the project on the farmers' livelihood, a five-point Likert scale was used and coded as follows: Strongly agree (5), Agree (4), Undecided (3), Disagree (2), and Strongly disagree (1). Also, a four-point Likert scale was used to assess the view of the farmers on the intensity of possible constraints facing the groups vis-à- 
vis their participation in the programme. This was rated as Very severe (4), Severe (3), Less severe (2), and Not severe (1).

\section{Results and discussion}

Socio-economic characteristics of the respondents

The distribution of the respondents according to their socio-economic attributes is shown in Table 2. Table 2 shows the socio-economic profile of the respondents. The majority of the respondents $(41.1 \%)$ were in the $56-60$ years of age-bracket. About $68.9 \%$ of the respondents were within the range of $61-75$ years. The mean age of the respondents was 62.5 years. These results suggest that the group mostly consists of aged adults.

Also $68.1 \%$ of the respondents were male, while $31.9 \%$ were females. This indicates the dominance of male individuals in the group. The majority (76.8\%) of the respondents were married, while just $0.5 \%$ was single. This suggests that crop farming is a means of catering for the family by the group.

Education is an important socio-economic factor as it determines the degree of innovativeness among farmers. About $35.7 \%$ of the respondents had no formal education, $22.7 \%$ attained primary education, and $15.7 \%$ attended secondary schools, while $3.2 \%$ and $1.6 \%$ had tertiary and adult education, respectively.

Household size is an important socio-economic variable as a large household size may determine the level of food security and poverty among farm households $[11,13]$. The household size of the respondents ranged from 1 to 10 persons. The modal group is $4-6$ persons, accounting for $59.5 \%$ of the respondents. Further analysis of the data revealed that the average household size of the respondents was about six persons.

Most (98.9\%) of the respondents had been in farming for more than ten years. Also, the mean farming experience of the respondents was 13.2 years. This suggests that crop farming is an age-long venture for the respondents.

Regarding secondary occupation, $47.6 \%$ of the respondents had no other job except crop production, $30.8 \%$ engaged in trading, while $11.4 \%$ reported that they were artisans. This stresses the fact that crop production is a means of meeting the livelihood needs of this group of farmers. 
Table 2. Distribution of respondents' personal characteristics $(\mathrm{n}=185)$

\begin{tabular}{|c|c|c|c|}
\hline Variable & Category & Frequency & Percentage \\
\hline & $56-60$ & 76 & 41.1 \\
\hline Age (years) & $61-65$ & 64 & 34.6 \\
\hline \multirow[t]{2}{*}{$($ Mean $=62.5$ years $)$} & $66-70$ & 34 & 18.4 \\
\hline & $71-75$ & 11 & 5.9 \\
\hline \multirow{2}{*}{ Sex } & Male & 126 & 68.1 \\
\hline & Female & 59 & 31.9 \\
\hline \multirow{5}{*}{ Marital status } & Single & 1 & 0.5 \\
\hline & Married & 142 & 76.8 \\
\hline & Widow & 37 & 20 \\
\hline & Separated & 3 & 1.6 \\
\hline & Widower & 2 & 1.1 \\
\hline \multirow{6}{*}{ Education } & No formal & 66 & 35.7 \\
\hline & Quranic & 39 & 21.1 \\
\hline & Primary & 42 & 22.7 \\
\hline & Secondary & 29 & 15.7 \\
\hline & Tertiary & 6 & 3.2 \\
\hline & Adult education & 3 & 1.6 \\
\hline \multirow{4}{*}{ Household size } & $1-3$ & 2 & 1.1 \\
\hline & $4-6$ & 110 & 59.5 \\
\hline & $7-9$ & 72 & 38.9 \\
\hline & $\geq 10$ & 1 & 0.5 \\
\hline \multirow{6}{*}{ Farming experience (years) } & $\leq 10$ & 2 & 1.1 \\
\hline & $11-15$ & 7 & 3.8 \\
\hline & $16-20$ & 33 & 17.8 \\
\hline & $21-25$ & 36 & 19.5 \\
\hline & $26-30$ & 77 & 41.6 \\
\hline & $>30$ years & 30 & 16.2 \\
\hline \multirow{4}{*}{ Secondary occupation } & None & 88 & 47.6 \\
\hline & Trading & 57 & 30.8 \\
\hline & Artisan & 21 & 11.4 \\
\hline & Others & 11 & 10.3 \\
\hline \multirow[t]{2}{*}{ Contact with Fadama facilitator } & & 185 & 100 \\
\hline & Regularly & 137 & 74.1 \\
\hline \multirow{3}{*}{ Frequency of contact with facilitator } & Occasionally & 48 & 25.9 \\
\hline & Rarely & 0 & 0 \\
\hline & Never & 0 & 0 \\
\hline \multirow{3}{*}{ Farm size (hectares) } & $<1.0$ & 73 & 39.5 \\
\hline & $1.1-2.0$ & 86 & 46.5 \\
\hline & $2.1-3.0$ & 26 & 14 \\
\hline \multirow{3}{*}{ Source of farmland } & Inheritance & 169 & 91.4 \\
\hline & Lease/rent & 5 & 2.7 \\
\hline & Purchase & 11 & 5.9 \\
\hline \multirow{3}{*}{ Source of labour } & Both family and hired & 10 & 5.4 \\
\hline & Family labour & 110 & 59.5 \\
\hline & Hired labour & 65 & 35.1 \\
\hline
\end{tabular}

Source: Authors' computation from field data 
All the respondents had contact with Fadama facilitators, who served as extension agents between the farmers and the programme's co-ordinating office. However, $74.1 \%$ of the respondents had contact with facilitators on a regular basis, while the remaining $25.9 \%$ had this contact just occasionally.

About $46.5 \%$ of the respondents operated between 1 and 2 hectares, while $39.5 \%$ operated on less than 1 hectare of farmland. The average farm size of the respondents was 1.44 hectares. These results indicate that this group of farmers were mainly smallholders. Ninety per cent of the respondents acquired their farmland through inheritance, $2.7 \%$ through lease/rent, while $5.9 \%$ acquired theirs through purchase. The major source of labour to the farmers was family labour, and this served as a source of labour to $59.5 \%$ of the farmers.

Activities/services benefited from the Fadama III programme by the respondents

Table 3 shows the activities/services rendered by Fadama to vulnerable aged users. The Table shows that in terms of asset acquisition all the respondents had knapsack sprayer, wheel barrow, and protective wears. Forty per cent benefited from irrigation tools, $81.6 \%$ benefited from agro-processing facilities, while $38.9 \%$ and $2.2 \%$ benefited from storage facilities and power tilling equipment, respectively. Also, regarding rural infrastructure, the majority $(73.5 \%)$ of the respondents benefited from potable water, $46.5 \%$ benefited from marketing facilities, but only $11.4 \%$ benefited from rural access roads.

Table 3 also indicates that all the respondents had access to input support, such as fertilizers, agrochemicals, and improved seeds, by virtue of participating in the programme. As regards advisory services, $98.4 \%$ of the respondents were trained on pest and disease control, $44.3 \%$ were trained on soil management, and $23.8 \%$ were trained on afforestation, while all the respondents were trained on sound agronomic practices. Regarding capacity building, $96.8 \%$ of the respondents were trained on how to resolve conflicts among users and non-users of the programme, $13 \%$ were trained on how to source market information, while all the respondents were trained on how to save and keep a proper record of their farming activities. 
Table 3. Distribution of respondents according to activities/services benefited from the Fadama III programme $(n=185)$

\begin{tabular}{llcccc}
\hline \multirow{2}{*}{ Category of benefit } & \multirow{2}{*}{ Benefits derived } & \multicolumn{2}{c}{ YES } & \multicolumn{2}{c}{ NO } \\
\cline { 2 - 5 } & & Freq. & $\%$ & Freq. & $\%$ \\
\hline & Storage facilities & 72 & 38.9 & 113 & 61.1 \\
& Irrigation facilities & 74 & 40 & 111 & 60 \\
& Agro-processing facility & 151 & 81.6 & 34 & 18.4 \\
Asset acquisition & Knapsack sprayer & 185 & 100 & - & - \\
& Wheel barrow & 185 & 100 & - & - \\
& Protective wears & 185 & 100 & - & - \\
& Power tiller & 4 & 2.2 & 181 & 978 \\
\hline \multirow{3}{*}{ Rural infrastructure } & Marketing facilities & 86 & 46.5 & 99 & 53.5 \\
& Rural access road & 21 & 11.4 & 164 & 88.6 \\
& Potable water & 136 & 73.5 & 49 & 26.5 \\
\hline \multirow{3}{*}{ Input support } & Fertilizers & 185 & 100 & - & - \\
& Agrochemicals & 185 & 100 & - & - \\
& Improved seeds & 185 & 100 & - & - \\
\hline \multirow{5}{*}{ Advisory services } & Agronomic practices & 185 & 100 & - & - \\
& Soil management & 82 & 44.3 & 103 & 55.7 \\
& Afforestation & 44 & 23.8 & 141 & 76.2 \\
& Sustainable land management & 2 & 1.1 & 183 & 98.9 \\
& Pest and disease control & 182 & 98.4 & 3 & 1.6 \\
\hline \multirow{3}{*}{ Capacity building } & Conflict resolution & 179 & 96.8 & 6 & 3.2 \\
& Savings/record keeping & 185 & 100 & - & - \\
& Market information & 24 & 13 & 161 & 87 \\
\hline
\end{tabular}

Source: Authors' computation from field data

\section{Influence of FADAMA III on the livelihood of the respondents}

Table 4 shows farm production by the respondents before and after participating in the programme. The majority $(57.8 \%)$ of the respondents cultivated between 0.6 and 1.0 ha of land for maize, $43.3 \%$ cultivated between 0.21 and 0.35 ha for cassava and $73 \%$ cultivated between 0.36 and 0.50 ha for yam. The output of most of the respondents were 1.1-1.5 tons/annum for maize, 2.1-4.1 tons/annum for cassava, and 3.1-4.5 tons/annum for yam, and this was obtained by $73.5 \%$, $41.6 \%$, and $73.0 \%$ of the respondents, respectively. The annual income of most of the respondents ranged from $\$ 51,000$ to $\$ 100,000$ for maize and cassava and from $\$ 101,000$ to $\$ 150,000$ for yam before the Fadama III intervention (Note: 1 US\$ = $\$ 165)$. 
Tab. 4: Status of the respondents before and after the Fadama III intervention

\begin{tabular}{|c|c|c|c|c|c|c|c|c|c|c|}
\hline Period & Crop & $\begin{array}{c}\text { Farm size } \\
(\mathrm{Ha})\end{array}$ & Freq. & $\%$ & $\begin{array}{l}\text { Output } \\
\text { (Tons) }\end{array}$ & Freq. & $\%$ & $\begin{array}{l}\text { Total } \\
\text { Amount } \\
\text { (N'000) }\end{array}$ & Freq. & $\%$ \\
\hline \multirow{9}{*}{$\begin{array}{l}\text { Before } \\
\text { Fadama III } \\
\text { intervention }\end{array}$} & \multirow{3}{*}{ Maize } & $0.1-0.5$ & 74 & 40 & $0.6-1.0$ & 45 & 24.3 & $1-50$ & 3 & 1.6 \\
\hline & & $0.6-1.0$ & 107 & 57.8 & $1.1-1.5$ & 136 & 73.5 & $51-100$ & 181 & 97.9 \\
\hline & & $1.1-1.5$ & 4 & 2.2 & $1.6-2.0$ & 4 & 2.2 & $101-150$ & 1 & 0.5 \\
\hline & \multirow{3}{*}{ Cassava } & $0.06-0.20$ & 77 & 41.6 & $0-2.0$ & 65 & 23.2 & $1-50$ & 3 & 1.6 \\
\hline & & $0.21-0.35$ & 80 & 43.3 & $2.1-4.1$ & 77 & 41.6 & $51-100$ & 144 & 77.8 \\
\hline & & $0.36-0.50$ & 28 & 15.1 & $4.2-6.2$ & 43 & 35.2 & $101-150$ & 38 & 20.6 \\
\hline & \multirow{3}{*}{ Yam } & $0.06-0.20$ & 28 & 15.1 & $0.1-1.5$ & 27 & 14.6 & $1-50$ & 23 & 12.4 \\
\hline & & $0.21-0.35$ & 22 & 11.9 & $1.6-3.0$ & 23 & 12.4 & $51-100$ & 40 & 21.6 \\
\hline & & $0.36-0.50$ & 135 & 73 & $3.1-4.5$ & 135 & 73.0 & $101-150$ & 122 & 66.0 \\
\hline \multirow{9}{*}{$\begin{array}{l}\text { After } \\
\text { Fadama III } \\
\text { intervention }\end{array}$} & \multirow{3}{*}{ Maize } & $0.1-1.0$ & 5 & 2.7 & $1.0-2.0$ & 4 & 2.2 & $10-100$ & 5 & 2.7 \\
\hline & & $1.1-2.0$ & 179 & 96.8 & $2.1-3.0$ & 178 & 96.2 & $110-200$ & 176 & 95.1 \\
\hline & & $2.1-3.0$ & 1 & 0.5 & $3.1-4.0$ & 3 & 1.6 & $210-300$ & 4 & 2.2 \\
\hline & \multirow{3}{*}{ Cassava } & $0.1-0.5$ & 43 & 23.3 & $0.1-4.5$ & 43 & 23.3 & $1-100$ & 3 & 1.6 \\
\hline & & $0.6-1.0$ & 53 & 28.6 & $4.6-9.0$ & 40 & 21.6 & $101-200$ & 142 & 76.8 \\
\hline & & $1.1-1.5$ & 89 & 48.1 & $9.1-13.5$ & 102 & 55.1 & $201-300$ & 40 & 21.6 \\
\hline & \multirow{3}{*}{ Yam } & $0.1-0.5$ & 8 & 4.3 & $0-3.0$ & 27 & 14.6 & $150-200$ & 3 & 1.6 \\
\hline & & $0.6-1.0$ & 26 & 14.1 & $3.1-6.1$ & 32 & 17.3 & $201-250$ & 5 & 2.7 \\
\hline & & $1.1-1.5$ & 151 & 81.6 & $6.2-9.2$ & 126 & 68.1 & $251-300$ & 177 & 95.7 \\
\hline
\end{tabular}

Source: Authors' computation from field data

After the Fadama III intervention, the majority (96.8\%) of the farmers cultivated between 1.1 and 20 ha of maize farmland with an output of about 2.13.0 tons/annum (by $96.2 \%$ of the respondents) and an annual income ranging from $\$ 110,000$ to $\$ 200,000$ (by $95.1 \%$ of respondents). About $48.1 \%$ of the respondents cultivated between 1.1 and 1.5 ha farmland with an output of 9.1-13.5 tons/annum (by $55.1 \%$ of respondents) and an annual income ranging from $\$ 201,000$ to $\$ 300,000$ (by $76.8 \%$ of the respondents) for cassava production. Also, $81.6 \%$ of the respondents cultivated between 1.1 and 1.5 ha of yam with an output between 6.2 and 9.2 tons/annum (for $68.1 \%$ of the respondents) and an annual income ranging from $\$ 251,000$ to $\$ 300,000$ (for $95.7 \%$ of the respondents) (Note: 1 US\$ = $\$ 165$ ).

\section{Effects of the Fadama III programme on the livelihood of the respondents}

Table 5 presents the distribution of respondents according to the perceived effects of the Fadama III project on their livelihoods. From the study, about $87.6 \%$ opined that their income increased through participation in the programme. The majority $(84.3 \%)$ of the respondents strongly agreed that they were able to enrol their children in school. This, they claimed, was due to their increased income and improvement in socio-economic status. Meanwhile, $74.6 \%$ of the respondents claimed that they had enough food available in storage and about $66.5 \%$ strongly agreed that Fadama III was a source of employment opportunity to them. Also, over $70 \%$ of the respondents claimed increased social interaction within the FUG 
group and $63.8 \%$ of the respondents agreed about having access to market information, which allowed them to sell produce beyond their localities. In the same vein, $86.5 \%$ agreed that their productive assets increased coupled with an improved standard of living through their participation in the programme. Likewise, the majority $(81.6 \%)$ of the respondents opined that they were able to obtain assistance from government and other donor agencies by virtue of participating in the programme.

Table 5. Distribution of respondents according to the perceived effects of Fadama III on their livelihood $(n=185)$

\begin{tabular}{|c|c|c|c|c|c|c|c|c|c|c|}
\hline \multirow{2}{*}{$\begin{array}{l}\text { Benefit derived } \\
\text { from FADAMA III }\end{array}$} & \multicolumn{2}{|c|}{$\begin{array}{l}\text { Strongly } \\
\text { agree }\end{array}$} & \multicolumn{2}{|c|}{ Agree } & \multicolumn{2}{|c|}{ Undecided } & \multicolumn{2}{|c|}{ Disagree } & \multicolumn{2}{|c|}{$\begin{array}{l}\text { Strongly } \\
\text { disagree }\end{array}$} \\
\hline & Freq. & $\%$ & Freq. & $\%$ & Freq. & $\%$ & Freq. & $\%$ & Freq. & $\%$ \\
\hline Increased income & 162 & 87.6 & 23 & 14.4 & - & - & - & - & & \\
\hline $\begin{array}{l}\text { Enrolment of } \\
\text { children in } \\
\text { education }\end{array}$ & 156 & 84.3 & 19 & 10.3 & - & - & 10 & 5.4 & - & - \\
\hline $\begin{array}{l}\text { Increased food } \\
\text { availability }\end{array}$ & 138 & 25.4 & 47 & 74.6 & - & - & - & - & - & - \\
\hline $\begin{array}{l}\text { Provide } \\
\text { employment } \\
\text { opportunity }\end{array}$ & 123 & 66.5 & 62 & 33.5 & - & - & - & - & - & - \\
\hline $\begin{array}{l}\text { Increased social } \\
\text { interaction }\end{array}$ & 47 & 25.4 & 130 & 70.3 & - & - & 8 & 4.3 & - & - \\
\hline $\begin{array}{l}\text { Access to market } \\
\text { information }\end{array}$ & - & - & 118 & 63.8 & 2 & 1.1 & 56 & 35.1 & - & - \\
\hline $\begin{array}{l}\text { Development of } \\
\text { new technology }\end{array}$ & - & - & 33 & 17.8 & 57 & 30.8 & 95 & 51.4 & - & - \\
\hline $\begin{array}{l}\text { Increase of own } \\
\text { productive assets }\end{array}$ & 160 & 86.5 & 8 & 4.3 & 17 & 9.2 & - & - & - & - \\
\hline $\begin{array}{l}\text { Assistance from } \\
\text { community }\end{array}$ & 17 & 9.2 & 16 & 8.6 & 86 & 46.5 & 66 & 35.7 & - & - \\
\hline $\begin{array}{l}\text { Assistance from } \\
\text { government/IDA }\end{array}$ & 151 & 81.6 & 27 & 14.6 & 7 & 8.3 & - & - & - & - \\
\hline
\end{tabular}

Source: Authors' computation from field data

\section{Challenges faced by the respondents}

The constraints limiting the respondents vis-à-vis their participation in the Fadama III programme are shown in Table 6. The foremost problem was the issue of pests and diseases, and this problem was faced by $85.9 \%$ of the respondents. This was followed by untimely release of funds with $87.6 \%$, inadequate input $(85.9 \%)$, limited income (73.5\%), and illiteracy $(65.9 \%)$. 
Table 6. Distribution of respondents according to constraints faced by them in accessing Fadama benefits $(n=185)$

\begin{tabular}{lcccccccc}
\hline \multirow{2}{*}{ Constraints } & \multicolumn{2}{c}{ Strongly Severe } & \multicolumn{2}{c}{ Severe } & \multicolumn{2}{c}{ Less Severe } & \multicolumn{2}{c}{ Not Severe } \\
\cline { 2 - 9 } & Freq. & $\%$ & Freq. & $\%$ & Freq. & $\%$ & Freq. & $\%$ \\
\hline Limited land & 36 & 19.5 & 18 & 9.7 & 107 & 57.8 & 24 & 13 \\
Pest and diseases & 159 & 85.9 & 18 & 9.7 & 8 & 4.3 & 0 & 0 \\
Inadequate input & 159 & 85.9 & 26 & 14.1 & 0 & 0 & 0 & 0 \\
Untimely release of funds & 162 & 87.6 & 23 & 12.4 & 0 & 0 & 0 & 0 \\
Inadequate funding & 144 & 77.8 & 41 & 22.2 & 0 & 0 & 0 & 0 \\
Poor access to information & 34 & 18.4 & 133 & 71.9 & 18 & 9.7 & 0 & 0 \\
Non-accessible roads & 0 & 0 & 103 & 55.7 & 59 & 31.9 & 23 & 12.4 \\
Conflicts with herdsmen & 12 & 6.5 & 117 & 63.2 & 53 & 28.6 & 3 & 1.6 \\
Illiteracy & 122 & 65.9 & 48 & 25.9 & 15 & 8.1 & 0 & 0 \\
Limited income & 136 & 73.5 & 47 & 25.4 & 2 & 1.1 & 0 & 0 \\
Poor attitude of users & 28 & 15.1 & 135 & 73 & 22 & 11.9 & 0 & 0 \\
Due process policy & 67 & 36.2 & 110 & 59.5 & 8 & 4.3 & 0 & 0 \\
Incompetency of service & 0 & 0 & 0 & 0 & 74 & 40 & 111 & 60 \\
providers & & & & & & & & \\
\hline
\end{tabular}

Source: Computation from field survey

Another important problem was the issue of conflicts between the farmers and herdsmen, about which $63.2 \%$ of the respondents agreed as being severe. Investigations during the survey revealed that the respondents' farmland was usually invaded by nomads in an attempt to source good pasture for cattle by the pastoralists. Poor access to information and non-accessible roads also posed severe problems to the activities of the farmers, with $71.9 \%$ and $55.7 \%$ of the respondents, respectively, agreeing about these constraints as being severe.

\section{Conclusions}

It can be inferred from this study that the Fadama III programme improved the livelihood of the vulnerable crop farmers in the study area. The study has been able to reveal an increase in farm size, farm output, income, and improvement in the livelihood of the vulnerable crop farmers after the Fadama III intervention. The programme also assisted the farmers in accessing input support, such as improved seeds, fertilizers, and agrochemicals, which enabled them to undertake farming operations as and when due. This group of farmers was also able to access new 
technology in best production practices and increased social interaction with other Fadama users. The programme also generated employment and increased food availability for family consumption and income. It also encouraged this vulnerable group to participate in agricultural development. However, this group of farmers were constrained by many factors vis-à-vis their access to full benefits from the programme. These problems include illiteracy, pests and diseases, inadequate inputs, and untimely funding, among others.

Based on these findings, therefore, there is need for government and relevant stakeholders to provide this group of farmers with education. The facilitators of the programme (and of similar programmes aimed at assisting vulnerable groups of people) could also assist them through non-formal education. This could be through adult literacy programmes and extension education. This would help in solving the problem of illiteracy this group of farmers is facing. Also, efforts should be overhauled in providing the farmers with adequate inputs. Besides, the facilitators of the programme (and of similar ones) should strengthen their efforts in giving the farmers practical training on pest and disease management as well as soil management. Moreover, agencies responsible for releasing the fund for such programmes should always make it timely, especially to this group of farmers. This is not only due to their condition but also to the seasonal nature of crop farming.

\section{Acknowledgement}

The authors sincerely appreciate the staff of Fadama Coordinating Office, Ilorin, Kwara State for their assistance during data collection.

\section{References}

[1] Population Reference Bureau (2013), 2013 World Population Datasheet. http://www.prb.org/ pdf13/2013-population-data-sheet_eng.pdf. (Accessed: 13.01.2014).

[2] Babatunde, R. O., Oyatoye, E. T. O. (2005), Food security and marketing problems in Nigeria: The case of maize marketing in Kwara State. The global food and product chain - dynamics, innovations, conflicts, strategies. Proceedings of Tropentag, 475-484.

[3] International Fund for Agricultural Development (IFAD) (2012), Enabling poor people to overcome poverty in Nigeria. http:/www.ifad.org/operations/projects/regions/pa/factsheets/ ng.pdf. (Accessed: 13.01.2015).

[4] Borokini, T. I., Okere, A. U., Giwa, A. O., Daramola, B. O., Odofin, W. T. (2010), Biodiversity and conservation of plant genetic resources in Field Genebank of the National Centre for Genetic Resources and Biotechnology, Ibadan, Nigeria. International Journal of Biodiversity and Conservation 2(3), 037-050.

[5] World Bank (2010), Poverty and equity (Nigeria: Country Indicators). http://povertydata. worldbank.org/poverty/country/NGA. (Accessed: 17.01.2015).

[6] Adewumi, M. O. (2013), The paradox of food insecurity in Nigeria. In: General studies in the social sciences and citizenship education: some fundamental topics, pp. 89-96. 
[7] Knowledge@SMU (2011), Addressing Singapore's unmet social needs: how to help vulnerable groups. Knowledge@SMU. http://ink.library.smu.edu.sg/ksmu/197. (Accessed: 13.03.2014).

[8] Chukwuemeka, E., Nzewi, H. N. (2011), An empirical study of World Bank agricultural development programme in Nigeria. American Journal of Social and Management Sciences 2(1), 176-187.

[9] Dakyes, S. P., Mundi, R. (2013), Impact of anti-poverty programme on development of rural areas of Nigeria. Ethiopian Journal of Environmental Studies and Management 6(1), 12-20.

[10] Eze, C. I. (2007). The multiplier effect of Agricultural Development Programme's (ADP's) Small Plot Adoption Technique (SPAT) on smallholder farmers in Abia State, Nigeria. Journal of Agriculture and Food Sciences 5(1), 41-51.

[11] Ike, P. C., Uzokwe, U. N. (2011), Estimation of poverty among rural farming households in Delta State, Nigeria. Int. J. Agric. Food Sci. Technol. 2(1), 11-21.

[12] Yakubu, R., Abbass, I. M. (2012), National Poverty Eradication Programme (NAPEP) and poverty alleviation in rural Nigeria: A case study of Giwa Local Government Area of Kaduna State. European Scientific Journal 8(18), 90-103.

[13] Ike, P. C. (2012). An analysis of the impact of Fadama III Project on poverty alleviation in Delta State, Nigeria. Asian Journal of Agricultural Sciences 4(2), 158-164. 